\title{
Impulsive Fashion Apparel Consumption: The Role of Hedonism, Fashion Involvement and Emotional Gratification in Fashion Apparel Impulsive Buying Behaviour in a Developing Country
}

\author{
Manilall Dhurup (Prof) \\ Executive Dean: Faculty of Management Sciences, Vaal University of Technology \\ Private Bag X021, Vanderbijlpark, 1900, Gauteng, South Africa \\ Email: royd@vut.ac.za.
}

\author{
Doi:10.5901/mjss.2014.v5n8p168
}

\begin{abstract}
Impulsive buying has been an enigma, intriguing yet captivating the minds of practitioners and researchers for more than half a century in various domains of study. In today's post-modern era, shopping has also emerged as a social and leisure activity, reducing the number of cognitively planned purchases, thus making impulsive buying a common practice and a socially acceptable phenomenon in developed and developing economies. This study complements the growing body of literature by examining three individual traits of human behaviour, namely hedonism, fashion involvement and emotional gratification and their effect on impulsive buying among a cohort of university students. The study is located within a post-positivist paradigm using a quantitative method. Participants were 385 randomly selected students registered in 2013 from a University in South Africa. Descriptive statistics were used to describe the composition of the sample. Correlations and regression analysis were used to test the relationships between the constructs. Validity and reliability were assessed through confirmatory factor analysis (CFA) and Cronbach alpha values. The results show that the three independent latent constructs, namely hedonic, fashion involvement and emotional gratification positively correlates with impulsive buying behaviour among the university cohort. However, only emotional gratification and fashion involvement were significant predictors of impulsive buying behaviour. For retailers and more specifically marketers, the constant need to generate opportunities for impulsive buying by appealing to consumers' fashion involvement and the emotional gratification side of life in apparel purchases becomes apparent for this cohort of consumers.
\end{abstract}

Keywords: Impulse buying, hedonic, fashion involvement, emotional gratification.

\section{Introduction}

With the growing levels of aspiration among university students to acquire better paying occupations, their desires are often fuelled through westernisation and the availability of an assortment of products in order to keep up to the trends of the times. For marketers and retailers, this cohort of consumers creates various opportunities in order to try to exploit their impulsive buying emotions (Kumar, 2007). Such changes has fixed the attention of retailers who found that South Africans shoppers spend as much as four times on alcohol than on out-of-pocket healthcare and one-and-a-half times more on clothes than on education (Statistics South Africa, 2011). Further, more than 18-million South African consumers have open credit accounts, and of these, 11-million people have clothing credit accounts. According to a recent survey in 2010/2011, on average, a South African household spent 4.5\% of their total household consumption budget on clothing and footwear (Statistics South Africa, 2011). Across the different population groups, Black African households spent a higher proportion (6.8\%) of their consumption expenditure on clothing and footwear, relative to the proportions spent by their Coloured (5.1\%), Indian/Asian (3.3\%) and White (2.1\%) counterparts. Whilst these statistics remain alarming, they do provide fertile grounds for retailers to better understand what lies beneath this nature of consumer spending behaviour, thereby changing consumers' share of the wallet.

The study of hedonism, fashion orientation and emotional gratification has been spurred as an area of research because of its apparent importance especially among university students as they are big spenders on fashion apparel especially among black consumers in South Africa. There is a rapid rise and distinctive demands of black consumers who are claiming the market space previously denied to them with marketers contending with this seismic shift (Chase, Legoete \& van Wamelen, 2010). In South very little research has been conducted on these constructs and particularly their influence on impulsive buying behaviour is still unknown. Hence, a gap remains in this area of research.

Impulsive human behaviour has been an area of study by psychologist, economist and consumer behaviour 
scholars since the 1950s (Burroughs, 1996; Piron, 1991; Rook, 1987; Youn, 2000). This phenomenon since then has become a distinct area of research and a panacea for management and marketers of businesses to accomplish commercial success through a strategic fit with the demand from consumers (Kotler \& Caslione, 2009). It is also acknowledged that in today's post-modern era, shopping has emerged as a social and leisure activity, reducing the number of cognitively planned purchases made by consumers (Banerjee \& Saha, 2012). Impulsive buying whilst intriguing; is an attractive and fascinating area of research. It has been an object of study for more than half a century in different fields of study, making it a common practice and socially acceptable in developed and developing countries. It is further an enigma in the marketing world as retailers and marketers grapple with innovative ways to increase sales and profits.

Fashion is a billion-dollar industry and fast evolving in many economies. It reflects society and a country's culture and how consumers define themselves. Consumers generally tend to equate fashion with clothing and accessories which is an essential part of an individual's well-being (Holmberg \& Öhnfeldt, 2010). When consumers buy clothes, they buy an identity (Tungate, 2008). Fashion is constituted like a pyramid. At the top of the pyramid, high fashion (haute couture) literally stands out. These are very exclusive garments manufactured by famous designers. Below this high-end fashion clothing is the ready-to-wear clothing that are not bespoke but still occupies an upper echelon associated with a high price tag (Holmberg \& Öhnfeldt, 2010). These designs are not necessary unique but rather produced in limited numbers. In the next level of the pyramid lie the challenger brands; the brands of clothing that are very fashionable but not as expensive as the well-known designer's ready-to-wear brands (Easey, 2009). Finally, at the bottom of the pyramid comprise mass retailing which are relatively cheap but still remain very trendy and savvy, where majority of consumers buy their clothes as they are seen as value for money (Tungate, 2008).

From the above discussion what needs to be borne in mind is that fashion market segmentation is cyclical and temporary which inter-alia are characterised by impulsive purchase, market demand, competiveness and the need to constantly to update clothing ranges with variety and assortments (Bhardwaj \& Fairhurst, 2010).

Against this backdrop, a brief background of apparel industry is provided in order to place the study into perspective within the industry in South Africa after its democratisation in a post-apartheid era. The liberalisation of the clothing sector, nationally after 1990 has been controversial due to its significant socio-economic contribution on one hand and the country's ability to compete in international markets on the other. According to the National Development and Labour Council (NEDLAC) (1995) soon after the 1990's the South Africa clothing industry has shown a huge downturn because of imported clothing which is linked to lower prices, labour cost and technology. Liberalisation of the market and subsequent competition with international companies has led to clothing factories closing down, resulting in large decreases in employment despite its propensity to be absorptive industry and its ability to offer entry-level jobs for unskilled millions of South Africans. Table 1 outlines the scenario of some indicators on the performance of the domestic apparel market in South Africa. Of interest is the labour cost per employee in terms of output. Output costs in terms of labour were almost 3.4 times more than international costs. In addition, the lead times, delivery reliability and absenteeism were also more significant than international counterparts. The results show that not only did the domestic apparel market face major international challenges but experience inherent competitiveness weaknesses (NEDLAC, 2005). This trajectory clearly points that only few firms will remain, employing a smaller number of people and servicing niche markets. In essence, South Africa has a high propensity to retrench employees in this sector, resulting in even higher levels of unemployment.

Table 1: Selected average comparative competiveness indicators for the apparel industry

\begin{tabular}{l|c|c|c}
\hline \multicolumn{1}{c|}{ Criteria } & SA Clothing & International Clothing & SA textiles \\
\hline Output per employee (rand '000) & 91.35 & 316,62 & 397.90 \\
\hline Total inventory (days) & 45.83 & 37.22 & 66.90 \\
\hline Customer return rate (\%) & 0.49 & 0.09 & 1.90 \\
\hline Customer delivery reliability (\%) & 86.67 & 89.38 & 88.0 \\
\hline Absenteeism (\%) & 7.93 & 4.66 & 4.04 \\
\hline
\end{tabular}

Source: Benchmarking \& Manufacturing Analysts (2005)

The purpose of the study was to establish impulsive consumption with specific reference on the relationship between hedonism, fashion involvement and emotional gratification in apparel impulsive buying behaviour. 


\section{Impulse Buying}

Stern (1962) earlier introduced a classification of a purchase either as a planned, unplanned or an impulse action. Planned purchases involve time-consuming information-searching with rational decision making, whereas unplanned purchases refers to all shopping decisions made without any advance planning. Impulse buying is distinguished from the unplanned buying in terms of quick decision making. In addition to being unplanned, an impulse purchase also involves experiencing a sudden, strong, and irresistible urge to buy (Muruganatham \& Bhakat, 2013) without any pre-shopping intention being formed before entering a store (Beatty \& Ferrell, 1998; George \& Yaoyuneyong, 2010). Bayley and Nancarrow (1998:99) defined impulse buying as a "sudden, compelling, hedonically complex buying behaviour in which the rapidity of an impulse decision process precludes thoughtful and deliberate consideration of alternative information and choices." Hedonic behaviour is marked with pleasure; in contrast to the utilitarian behaviour where the shoppers seek functional and economic value in the shopping process.

Earlier studies on impulse buying were concerned with issues of definition, distinguishing impulse buying from nonimpulse buying and attempted to classify the types of impulse buying into one of several categories (Kollat \& Willett, 1969; Bellenger, Robertson, Hirschman, 1978). Such an approach lacked the understanding of impulsive buying as a trait emerging from consumer buying behaviour. Traits represent pre-dispositional attributes of personality that refers to a person's unique psychological makeup (Park \& Lennon, 2009). A theoretical model of impulsive buying developed by Beatty and Ferrell (1998) and the consumption impulse formation and enactment (CIFE) model developed by Dholakia (2000) considered impulsive buying as a trait that contributes to an understanding to the formation of the consumption impulse. Despite negative aspects concerning impulsive buying behaviour in past research, it does account for substantial sales across a range of product categories (Han, Morgan, Kotsiopolos \& Kang-Park, 1991). The pervasiveness of impulse buying, even for relative expensive products like apparel, led researchers to examine impulse buying as an inherent individual trait, rather than a response to inexpensive product offerings (Cobb \& Hoyer, 1986). Thus impulsive buying as a consumer trait may be positively related to the actual impulsive buying (Park \& Lennon, 2009).

Compulsive buying on the other hand is a chronic, repetitive purchasing that becomes a primary response to negative events or feelings (O'Guinn \& Faber, 1989). Compulsive buyers tend to buy excessive number of products they do not need and sometimes cannot afford (Hoyer \& Maclnnis, 2001). Compulsive buying is different from impulsive buying as the latter is temporary, while the former is an enduring behaviour that centres on the process of buying and the actual purchases (Solomon, 2004).

\subsection{Hedonic variables and impulse buying}

In broad terms, shopping motivations have been categorised into two aspects; hedonic and utilitarian. Hedonic consumption includes those behavioural aspects related to multi-sensory and fantasy which are driven by benefits such as fun in actually buying the product or fun in using the product, shopping for adventure and for socialisation (Arnold \& Reynolds, 2003). Impulsive purchase behaviour is driven by hedonistic or pleasure seeking goals which causes a consumer to experience a desire for products (Virvilaitè \& Saladiené, 2012). The utilitarian shopping behaviour on the other hand is characterised by task-related, product-oriented, rational and extrinsic motivations (Babin, Darden \& Griffen, 1994).

According to Overby and Lee (2006) hedonic shopping value is far more subjective, personal and experiential than its utilitarian counterpart. The hedonic shopping value reflects shopping's potential entertainment value and the possible symbiotic and/or synergistic relationship between the consumers and their shopping reference group(s). Hedonic consumption tendency influences consumers purchase amount directly and indirectly, by positive emotion (Amiri, 2012).The hedonic shopping value reflects the value found in the shopping experience itself, independent of task related activities (Overby \& Lee, 2006). Thus consumers are more likely to engage in impulse buying when they are motivated by hedonic desires or by non-economic reasons (Hausman, 2000). In addition, apparel-oriented impulse buying behaviour may be motivated by new versions of fashion styles which drive consumers' hedonic shopping experiences (Goldsmith \& Emmert, 1991). Based on these assertions the following hypothesis is formulated for the study.

H1: The hedonic motive for shopping positively influences impulsive buying behaviour among students, during shopping. 


\subsection{Emotional gratification and impulse buying}

An emotion is referred to as a strong, mental or instinctive feeling that affects a customer's behaviour and is virtually uncontrollable in nature (Hawkins, Best \& Coney, 2001). Although previous research indicates that there is an element of fun involved in impulse buying, there is also evidence suggesting that impulse buying serves the function of alleviating unpleasant psychological states. For example, Mick and DeMoss (1990:322) revealed that people sometimes reward themselves with "self-gifts" as a means of elevating a negative mood. Kacen and Lee (2002) affirm that consumers often choose to sacrifice self-control and allow themselves to make impulsive purchases if they think such purchases might make them feel better. Positive emotion can be elicited by an individual's pre-existing mood, affective disposition and reaction to current environmental encounters such as a sales promotion. Researchers affirm that emotions strongly influence actions including impulsive buying (Beatty \& Ferrell 1998; Youn \& Faber, 2000). High impulsive buying may be influenced by emotional attraction (irrational) rather than rational judgements (such as price). Moreover, in social psychology, apparel could be seen as an important symbolic meaning for consumers to construct and express their selfidentity and they often 'dress the part' with one's social environment (Babin \& Babin, 2001:91). Based on these assertions it is therefore hypothesised that:

\section{H2: Emotional gratification positively influences impulse buying behaviour among students, during shopping.}

\subsection{Fashion involvement and impulse buying}

The notion of fashion also involves consumption behaviour that displays an individual's tastes and values, given that fashion styles are usually accepted by a large group of people at a particular time and signify both social identification and distinction (Gronow, 1997). This term further refers to clothing and other physical and material objects put on the human body (Kaiser, 1997).Thus, the term fashion can be applied to all aspects of someone's personal appearance that provide both hedonic and utilitarian value to consumers (Bannister \& Hogg, 2004).

Involvement is a motivational state of arousal or interest evoked by a particular stimulus or situation and displayed through properties of drive (O'Cass, 2004). In apparel marketing, fashion involvement refers to the extent of interest with a fashion product. Fashion involvement refers to the extent to which an individual is caught up in a number of fashionrelated concepts, including awareness, knowledge, interest, and reactions. Given this range of concepts, fashion can become a central focus for a meaningful and engaging activity in an individual's life. Fashion involvement basically relates to fashionable clothing and refers to the degree of importance to the category of fashion products and their influence of impulsive buying behaviour (Park, Kim \& Forney, 2006). Thus fashion involvement is the level of involvement by consumers with fashionable clothing.

O'Cass (2004) contends that the continual and cyclic nature of fashion means that people are often drawn into the style of the moment and such consumers place great emphasis on their clothes being in vogue. Researchers like Cha (2001) and Han et al. (1991) found that impulse buying of apparel is related to being fashion oriented. Therefore, students who have a high level of fashion involvement are more likely to generate the emotions needed for an impulse purchase. Based on these assertions, the following hypothesis is set:

H3: Fashion involvement is positively influences impulse buying behaviour among students, during shopping.

Based on these hypotheses the following conceptual framework has been developed for the study.

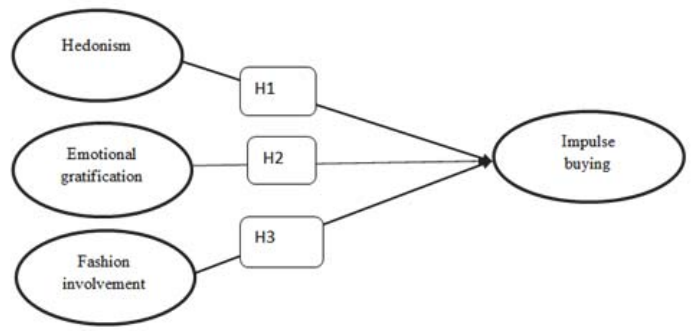

Figure 1: Proposed framework of relationships 


\section{Methodology}

A quantitative research paradigm was used in the study as the research sought to find relationships between variables through statistical techniques, namely correlations and regression analysis.

\subsection{Participants and sample}

Participants in the study were 385 students randomly selected from undergraduate and post graduate programmes from a University in Southern Gauteng, South Africa. A list of students was generated from the Integrated Tertiary Software system (ITS) of the University. University students were primarily chosen for the study as Wood (1998) identified that impulse purchase is more frequent in younger adults engaged in university education and that levels of education beyond high school is significantly associated with impulse buying behaviour. In addition, these students are the next generation of employees in the workplace who may add value towards an understanding of buying behaviour. Participation in the survey was voluntary and respondents were also assured that their responses would remain confidential and anonymous.

\subsection{Measures and data collection}

In order to achieve the objectives of the current study, a comprehensive literature review was conducted on the identified variables used in the study. The questionnaire was divided into three sections. Section A consisted of questions related to demographic information, shopping orientation which inter-alia included: gender, age, ethnicity, shopping frequency and shopping companion. Section B comprised questions on hedonistic, emotional gratification and fashion involvement with regard to impulse buying. Section $C$ elicited questions on impulse buying behaviour. A structured self-administered questionnaire was used to collect the data. The questionnaire was compiled using Likert scales adapted from previous relevant research studies (Park, et al., 2006, Rook and Fisher, 1995; Weinberg and Gottwald, 1982, Rook, 1987; Chen, 2001; Hausman, 2000) on impulsive buying behaviour. The questions were developed on a 7-point Likert scale, anchored by 7 denoting strongly agree, 4 denoting moderately agree and 1 denoting strongly disagree. The Likert scale was utilised because it is relatively easy to construct, makes data easy to collect and analyse, thereby making it suitable for surveys (DeVellis, 2003; Kothari, 2009). Pre-testing was conducted with a conveniently selected sample of five academics in marketing and consumer behaviour in order to ensure that the questionnaire met expectations in providing accurate information, usage of appropriate wording, questioning sequence and also to assess the extent to which respondents understood the questions clearly. The pre-test also served to determine the anticipated questionnaire completion time.

\section{Reliability and Validity}

To assess reliability, Cronbach's alphas were calculated for the fours scales, namely, hedonism, emotional gratification, fashion involvement and impulsive buying. All four scales showed good reliability, as follows: fashion involvement $(a=$ 0.927), hedonism ( $\alpha=0.824)$ emotional gratification $(\alpha=0.829)$ and impulsive buying $(\alpha=0.737)$. Using AMOS 21.0, a confirmatory factor analysis was conducted. The factor loadings for the all four constructs ranged from 0.50 to 0.828 , showing that each of the scales was indeed based on one underlying factor. Table 2 summarises the means, reliability and accuracy statistics conducted through a confirmatory factor analysis approach.

Table 2: Reliability and accuracy statistics using CFA

\begin{tabular}{l|c|c|c|c|c}
\hline \multicolumn{1}{c|}{ Research constructs } & Means & Cronbach's tests $\boldsymbol{\alpha}$ & C.R. value & AVE value & Shared variance \\
\hline Construct 1: Fashion involvement (FAS) & 4.03 & 0.927 & 0.93 & 0.55 & 0.32 \\
\hline Construct 2: Hedonism (HED) & 4.46 & 0.824 & 0.79 & 0.51 & 0.32 \\
\hline Construct 3: Emotional gratification (EMG) & 3.84 & 0.829 & 0.83 & 0.72 & 0.32 \\
\hline Construct 4: Impulsive buying (IMB) & 2.69 & 0.736 & 0.75 & 0.53 & 0.11 \\
\hline
\end{tabular}

Note: C.R.: Composite Reliability; AVE: Average Variance Extracted; Scores: 1= Strongly Disagree; 4=Moderately agree; $7=$ Strongly Agree.

All the composite reliability (CR) values were above the recommended threshold value of 0.70 which confirms the internal consistency and reliability of the respective measures used in the study (Hulland, 1999). Further the average variance extracted (AVE) values were above the recommended threshold value of 0.50 (Bryne, 2001). Discriminant validity was 
established by checking if the lowest AVE value for each construct was greater than the highest shared variance (SV) between constructs (Nunnally \& Bernstein, 1994; Fornell \& Larcker, 1981). The lowest AVE value was 0.55 which is greater than the highest shared variance between the constructs of 0.32 thus providing evidence of discriminant validity. Overall, the results of the CFA provide sufficient evidence that the measurement scales used were reliable and valid (Chinomona, Dhurup \& Chinonoma, 2013).

\section{Results and Discussion}

The collected data were analysed using the Statistical Packages for the Social Sciences (SPSS) version 21.0 and Analysis of Moment Structures (AMOS) version 21.0.

\subsection{Sample composition}

The sample comprised $55 \%$ ( $n=209)$ females and $46 \%$ ( $n=176)$ males. Majority of the students, $46 \%(n=175)$ were under 22 years of age. Newspapers and magazines were the most popular reported media, $56 \%(n=214)$ from which students obtained information on where and what kind of clothing to buy. Boutiques that were located in malls were the most popular, $43 \%(n=166)$ were majority of the students shopped for clothing and accessories. In terms of impulsive buying tendencies, $31 \%(n=121)$ of the students admitted to making such purchases in the past two months.

\subsection{Exploratory factor analysis}

Exploratory factor analysis was conducted using Principal component analysis with Varimax rotation and Kaiser Normalisation. This is a statistical technique used to identify a set of latent (hidden) constructs underlying a battery of measured variables (Norris \& Lecavalier, 2009). To determine whether the data were suitable for a factor analysis, the Bartlett's test of Sphericity and the Keiser-Meyer-Olkin (KMO) measure of sampling adequacy were conducted, as recommended by Pett, Lackey and Sullivan (2003). The Bartlett's test of Sphericity was significant at $p<0.000$, from which it could be inferred that the data set was not an identity matrix with zero correlations and was suitable for factor analysis (Aldlaign \& Buttle, 2002). The KMO measure of sampling adequacy was 0.928 , is considered satisfactory by Malhotra (2010), signifying that the data were suitable for factor analysis. Items that loaded heavily (cross-loadings) on more than one factor were eliminated from further scale refinement. Items were also eliminated because of low factor loading $(<0.50)$ (Maholtra, 2010). This procedure resulted in the removal of four variables from the original data set. A summary of the factors, their respective descriptions and the cumulative percentage of variance is reported in Table 3 . The three factors accounted for approximately $62 \%$ of the explained variance which is considered acceptable (Malhotra, 2010).

Table 3: Factors, descriptions of factors and cumulative percentage of variance extracted

\begin{tabular}{l|l|c}
\hline \multicolumn{1}{c|}{ Factors label } & \multicolumn{1}{c|}{ Factor description } & $\%$ of variance \\
\hline Fashion involvement & $\begin{array}{l}\text { Fashion involvement refers to the extent of interest with a fashion product e.g. } \\
\text { apparel. }\end{array}$ & 44.102 \\
\hline Hedonistic & $\begin{array}{l}\text { A characteristic measuring the degree to which a consumer finds pleasure in the } \\
\text { shopping activity and shops for the fun of it. }\end{array}$ & 11.812 \\
\hline Emotional gratification & $\begin{array}{l}\text { Emotion gratification is an elicitation by consumers existing mood and affect which } \\
\text { results in feeling uplifted or energised after a shopping experience. }\end{array}$ & 6.147 \\
\hline Cumulative \% of variance explained & 62.062 \\
\hline
\end{tabular}

\subsection{Confirmatory Factor Analysis and goodness of fit measures}

In accordance with the procedure suggested by Anderson and Gerbing (1988), a confirmatory factor analysis (CFA) was performed to examine reliability, convergent and discriminant validity of the multi-item construct measures using AMOS 21.0. Overall acceptable model fit are indicated by Goodness-of-Fit Index (GFI) $\geqq 0.90$; Adjusted Goodness-of Fit Index $(A G F I) \geqq 0.90$; Root Mean Square Error of Approximation (RMSEA) values $\leqq 0.08$; Incremental Index of Fit (IFI), TuckerLewis Index (TLI) and Comparative it Index (CFI) values $\geqq 0.90$; and Chi-square degrees of freedom ratio (CMIN/DF) value $<3$ (Fornell \& Larcker, 1981; Browne \& Cudeck, 1993). Recommended statistics for the final overall model 
assessment show acceptable fit of the measurement model to the data, $\mathrm{CMIN} / \mathrm{DF}=2.064 ; \mathrm{GFI}=0.916 ; \mathrm{IFI}=0.953 ; \mathrm{TLI}=$ 0.944; $\mathrm{CFI}=0.952 ; \mathrm{RMSEA}=0.053$.

Correlations were computed between the selected impulsive buying traits with impulsive buying in order to establish the strength and direction of the relationship. The results are reported in Table 4.

Table 4: Correlations-impulsive buying behaviour traits with impulsive buying

\begin{tabular}{l|c|c|c|c|c}
\hline \multicolumn{1}{c|}{ Variables } & $\mathbf{N}$ & Fashion involvement & Hedonism & Emotional gratification & Impulsive buying \\
\hline Fashion involvement & 385 & 1 & & & \\
\hline Hedonism & 385 & $.564^{* *}$ & 1 & & \\
\hline Emotional gratification & 385 & $.299^{* *}$ & $.489^{* *}$ & 1 & $.225^{* *}$ \\
\hline Impulsive buying & 385 & $.329^{* *}$ & $.251^{* *}$ & & 1 \\
\hline${ }^{*}$ Correlations are significant at $p<0.05$ level
\end{tabular}

Moderate positive correlations were found between fashion involvement and impulsive buying $(r=0.429 ; p<0.05)$, hedonism and impulsive buying $(r=0.431 ; p<0.05)$ and emotional gratification and impulsive buying $(r=0.290 ; p<0.05)$. Karbasivar and Yarahmadi (2011) identify these traits as internal to an individual that makes them engage in impulsive buying behaviour. Muruganatham and Bhakat (2013) also affirms that fashion-orientation and fashion involvement is also a trait that consumers display when faced with new fashion styles and brands which drive consumers to impulsive buying.

In terms of the hedonic desire to engage in impulsive buying, Hausman (2000) argues that these needs are predominantly motivated by achievement of higher order needs grouped according to Maslow's hierarchy of needs and thus efforts to satisfy the higher order needs in this hierarchy lead to impulsive behaviour. In terms of emotional gratification, Verplanken and Herabadi (2001) also revealed that impulsive buying was associated with individuals who want to escape from negative psychological perceptions such as low esteem, negative feelings or moods.

\subsection{Regression analysis-impulsive buying behaviour traits and impulsive buying}

The regression model summary is reported in Table 5 . The regression model indicates that approximately $12 \%$ of the variance in impulsive buying can be explained by fashion involvement, hedonism and emotional gratification. In terms of the beta weighs fashion involvement $(\beta=0.270 ; t=4.663 ; p<0.000)$ and emotional gratification $(\beta=0.126 ; t=2.228 ; p<0.05)$ contributes significantly towards impulsive buying behaviour.

Table 5: Regression analysis-impulsive buying behaviour traits and impulsive buying

\begin{tabular}{|c|c|c|c|c|c|c|c|}
\hline \multirow{3}{*}{$\begin{array}{l}\text { Variable relationships } \\
\text { (independent) }\end{array}$} & \multicolumn{5}{|c|}{ Dependent variable: impulsive buying behaviour } & \multicolumn{2}{|c|}{ Collinearity statistics } \\
\hline & \multicolumn{2}{|c|}{$\begin{array}{l}\text { Unstandardized } \\
\text { coefficients }\end{array}$} & \multirow{2}{*}{$\begin{array}{c}\text { Std coefficients } \\
\text { Beta }\end{array}$} & \multirow[t]{2}{*}{ t-value } & \multirow[t]{2}{*}{ Sig } & \multirow[t]{2}{*}{ Tol } & \multirow[t]{2}{*}{ VIF } \\
\hline & Beta & Std. error & & & & & \\
\hline Fashion involvement & 1.066 & 0.245 & 0.270 & 4.663 & $0.000^{*}$ & 0.682 & 1.467 \\
\hline Hedonism & 0.037 & 0.063 & 0.038 & 0.592 & 0.554 & 0.570 & 1.755 \\
\hline Emotional gratification & 0.096 & 0.042 & 0.126 & 2.228 & $0.023^{*}$ & 0.760 & 1.315 \\
\hline
\end{tabular}

However, hedonism showed no significant relationship ( $p>0.05)$ with impulsive buying behaviour among university students. These results resonate with the findings of Park, et al. (2006) which revealed no direct relationship between hedonic consumption and impulsive buying among university students. A plausible reason for this may be that university students are largely driven by fashion-orientation and involvement, motivated primarily by the desire to have new design and styles of clothing as part of their collection and they seem to align more towards unplanned purchases which are linked more with emotional gratification (Cha, 2001). Weinberg and Gottwald's (1982) study also affirms the hedonic relationships with impulsive buying exhibited greater feelings of amusement, delight, enthusiasm and joy.

Hence, the hypothesis $\mathrm{H} 1$ which states that hedonic motive for shopping positively influences impulsive buying behaviour among students, during shopping is not supported.

With regard to emotional gratification, these results support previous studies which have demonstrated that emotions strongly influence impulsive buying (Beatty \& Ferrell, 1998; Hausman, 2000, Youn \& Faber, 2000). Consumers 
in more positive emotional states tend to have reduced decision complexity (Isen, 2001). Moreover, previous research showed that consumers with positive emotion exhibited greater impulse buying because of the feelings of being unconstrained and a desire to rewards themselves (Rook \& Gardner, 1993). Chang, Eckman and Yan's study (2011) established that consumers who had more positive emotional responses to the retail environment showed greater propensity to make impulsive purchases.

Hence, the hypothesis $\mathrm{H} 2$ which states that emotional gratification positively influences impulse buying behaviour among students, during shopping is supported.

With regard to fashion involvement, Seo, Hathcote and Sweaney (2001) also found significant predictive relationship with impulse buying suggesting that consumers with high fashion involvement were more likely to engage in fashion-oriented impulse buying. Park, et al. (2006) study of university students further lend support to the positive relationship between fashion involvement and impulsive buying behaviour which revealed that students with high fashion involvement were more likely to experience positive outcomes during shopping.

This findings support $\mathrm{H} 3$ which states that fashion involvement is positively influences impulse buying behaviour among students, during shopping is therefore supported.

The strategic implication for owners/managers of fashion stores is to pay more attention to the hedonic and their emotional side of consumers through promotional material, affordable pricing, discounts, increasing the selling ability of sales personnel so that they interact longer with customers and by allowing adequate time for consumers to try out different fashion products. In addition, store owners/managers should constantly provide new experiences for consumers and try to satisfy their curiosity by creating store layout that induce impulsive buying by creating a sense of excitement and satisfaction through service and the friendliness of store employees. Impulsive shoppers are very important to the retail trade industry. Material used to communicate to consumers in retail shops may require detailed adaptation in order to attract shoppers who are motivated for different hedonic reasons, keeping in mind that they are a significant proportion of the shopping public. Retailers can achieve this by making the total shopping experience an adventure or a place in which to relieve tension and stress. Retailers need to offer attractive décor and an exciting shopping experience, by making creative use of atmospherics, for example, creative merchandising, appropriate lighting, music and appropriate aromas. The fact that impulsive shoppers use shopping for information seeking and may not actually acquire a product, accentuates the need for effective in-store promotions. Positive buying emotion and mood management are significant components of the affective process, which is why retailers should constantly work on creating a positive shopping environment. Store atmospherics is essential in attracting and keeping the consumers excited about the shopping experience. This will help to enhance mood and emotion, which may trigger affective tendencies leading to impulsive buying behaviour.

\section{Limitations and Implications for Future Research}

While this study has its limitations, which are addressed in this section, they also provide directions for future research for researchers interested in the retail sector. This study was conducted in one university and in one region of the country, which limits the representativeness and generalisation of the results. Future research should be conducted which expands this study to include a non-student sample, demographic subcultures, social classes and lifestyle factors. Also of interest would be to explore impulsive buying tendencies through the Internet (online shopping). The research focused primarily on three variables that induce impulse buying in developing countries. Clothing impulse buying needs to be extended to include other consumer characteristics and situational factors such as personality, loyalty, and time and money availability. The study could also be extended to different product categories such as home furnishings and cosmetics. The research into this issue has twofold significance, i.e. it is important to both marketing and management experts because it provides an additional explanation of impulsive buying and comprehension of respondents' behaviour, especially in terms of personal traits and their impact on impulse buying. Also, the results of this research will has practical value by providing the managers with useful insights that will allow them to create some elements of marketing strategy, e.g. adaptation or alteration of some sales promotion techniques, in-store environments. Retailers should pay attention to consumer's positive emotional state since these aspects seem to trigger impulsive purchases.

\section{Conclusion}

The finding of the research has the potential to enrich the body of knowledge among academics as well as practitioners. In this study, relationships have been hypothesized based on theory. Impulse buying has been a challenge and will still remain an enigma for market researchers due to its complex nature. Hausman (2000) mentioned that impulse buying is a 
complicated and multifaceted phenomenon which accounts for a huge volume of the products sold every year. In the emerging economies, there is a need to study impulse buying due to recent development in retailing and huge cultural differences when compared to developed economies.

\section{References}

Aldlaign, A. H., \& Buttle, F. A. (2002). SYSTRA-SQ: a new measure of bank service quality. Industrial Journal of Service Industry Management, 13:362-381.

Amiri, F.J., Shirpour, J.M., \& Alizadela, T. (2012). Evaluation of effective fashionism involvement factors effects on impulse buying of customers and condition of interrelation between these factors. Journal of Basic and Applied Scientific Research, 2(9): 9413-9419.

Anderson, J.C., \& Gerbing, D.W. (1988). Structural equation modelling in practice: A review and recommended two-step approach. Psychological Bulletin, 103(3):411-423.

Arnold, M.J., \& Reynolds, K.E. (2003). Hedonic shopping motivations. Journal of Retailing, 79(2):77-95.

Babin, B.J., \& Babin, L. (2001). Seeking something different? A model of schema typicality, consumer affect, purchase intentions and perceived shopping value. Journal of Business Research, 54(20): 89-96.

Babin, B.J., Darden, W.R., \& Griffin, M. (1994). Work and/or fun? Measuring hedonic and utilitarian shopping value. Journal of Consumer Research, 26(4): 644-656.

Banerjee, S., \& Saha, S. (2012). Impulsive buying behaviour in retail stores-triggering the sense. Asia Pacific Journal of Marketing \&Management Sciences, 1(2):1-21.

Bhardwaj, V., \& Faithurst, A. (2010). Fast fashion: response to changes in the fashion industry. The International Review of Retail, Distribution and Consumer Research, 20165-173.

Beatty, S. E., \& Ferrell, E.M. (1998). Impulse buying: modelling its precursors". Journal of Retailing, 74(2): 169-191.

Banister, E.N., \& Hogg, M.K. (2004). Negative symbolic consumption and consumer's drive for self-esteem: the case of the fashion industry. European Journal of Marketing, 38:850-868.

Bayley, G., \& Nancarrow, C. (1998). Impulse purchasing: a qualitative exploration of the phenomenon. Qualitative market Research: An International Journal, 1(2):99-114.

Benchmarking and Manufacturing Analysts. (2005). Firm level competiveness data. uww.bmanalysts.com. Date retrieved: 16 February 2014.

Bellenger, D.N., Robertson, D.H., \& Hirschman, E.C. (1978). Impulse buying varies by Product. Journal of Advertising Research, 18(10):1518.

Browne, M.W., \& Cudeck, R. (1993). Alternative ways of assessing model fit. In Testing Structural Equation Models, (eds.) K.A Bollen, J.S. Long (pp. 136-161), Newbury Park, CA: Sage,

Burroughs, J.E. (1996). Product symbolism, self-meaning and holistic matching: the role of information processing in impulsive buying". Advances in Consumer Research, 23:463-469.

Byrne, B.M. (2001). Structural equations modelling with AMOS. Mahwah, N.J: Lawrence Erlbaum Associates.

Cha, J. (2001). Planned and unplanned apparel purchase typology and related variables. Unpublished theses, Seoul National University, Seoul.

Chase, B., Legoete., T., \& van Wamelen , A. (2010). A seismic shift in South Africa's consumer landscape. http://www.mckinsey.com/insights Iconsumer_and_retail/a_seismic_sh

Chang, H.J., Eckman, M., \& Yan, R.N. (2011). Application of the stimulus-organism-response model to the retail environment: the role of hedonic motivation in impulsive buying behaviour. The International Review of Retail, Distribution and Consumer Research, 21(3): 233-249.

Chinomona, R., Dhurup, M., \& Chinomona, E. (2013). Does employee perceptions of fit to job, fit to organisation and fit to community influence job performance? The case of Zimbabwe's manufacturing sector". SA Journal of Human Resources Management. ISA TydskrifvirMenslikehulbronbestuur, Vol.11, No.1, Art\#475., 10 pages. http://dx.doi.org/10.4102/sajhrm.v11i.475.

Chen, M. H. (2001). The determinants and traits of Impulsive buying behaviour, Journal of Takming University, 17:59-74.

Cobb, J.C., \& Hoyer, W.D. (1986). Planned versus impulse purchase behaviour. Journal of Retailing, 62(4): 384-409.

DeVellis, R. F. (2003). Scale development: theory and applications. Thousand Oaks, CA: Sage.

Dholakia, U.M. (2000). Temptation and resistance: an integrated model of consumption impulse formation and enactment. Psychology and Marketing, 17(10): 955-982.

Easey, M. (2009). Fashion marketing. (3rd ed.). Oxford: Wiley-Blackwell.

Fornell, C., \& Larcker, D. (1981). Evaluating structural equation models: LISREL and PLS applied to consumer exit-voice theory. Journal of Marketing Research, 19(40):440-452.

George, B.P., \& Yaoyuneyong, G. (2010). Impulsive buying behaviour and cognitive dissonance: a study conducted among the spring break student shoppers. Young Consumers, 11(40): 291-306.

Goldsmith, R.E., \& Emmert, J. (1991) . Measuring product category involvement: a multitrait-multimethod study. Journal of Business Research, 15:127-130.

Gronow, J. (1997). The Sociology of Taste. London: Routledge.

Hausman, A. (2000). A multi-method investigation of consumer motivations in impulse buying behaviour. Journal of Consumer Marketing, 17(5):403-426.

Han, Y.K., Morgan. G.A., Kotsiopulos, A., \& Kang-Park, J. (1991). Impulsive buying behaviour of apparel purchasers. Clothing and Textiles 
Research Journal, 9(3):15-21.

Hawkins, D.I., Best, R.J., \& Coney, K.A. (2001). Consumer Behaviour. (8thed.). New York: McGraw-Hill.

Hoyer, W., \& MacInnis, D. (2001). Consumer Behaviour. (2nd ed.). Boston, MA: Houghton Mifflin Company.

Holmberg, J., \& Öhnfeldt, R. 2010. The female fashion consumer behaviour: from the perspective of the shop Fever in Gothenburg. Bachelor Thesis, Gothenburg. Sweden.

Hulland, J. (1999). Use of partial least squares (pls) in strategic management research: a review of four recent studies. Strategic Management Journal, 20(2):195-204.

Isen, A.M. (2001). An influence of positive affect on decision making in complex situations: theoretical issues with practical implications". Journal of Consumer Psychology, 11(2): 75-85.

Kacen, J.J., \& Lee, J.A. (2002). The Influence of culture on consumer impulsive buying behaviour. Journal of Consumer Psychology, 12(2):163-179.

Kaiser, S.B. (1997). The Social Psychology of Clothing. (2nded.). Fairchild Publications, New York, NY.

Karbasivar, A., \& Yarahmadi, H. (2011). Evaluating effective factors on consumer impulsive buying behaviour. Asian Journal off Business Management Studies, 2(4):174-181.

Kollat, D. T., \& Willett, R. P. (1969). Is impulse purchasing really a useful Concept for marketing decisions? The Journal of Marketing, 33: 7983.

Kotler, P., Caslione, J. (2009). How marketers can respond to recession and turbulence? Journal of Consumer Behaviour, 8(2):187-191.

Kothari, C. R. (2009). Research methodology: methods and techniques. (2ndEd.). New Delhi: New Age International.

Kumar, R. (2007). Marketing and Branding: Indian scenario. New Delhi: Pearson Education.

Malhotra, N.K. (2010). Marketing research: an applied orientation. (6 ${ }^{\text {thed. }}$.). NJ: Pearson Prentice-Hall.

Mick, D.G., \& DeMoss, M. (1990). Self-gifts: phenomenological insights from four contexts. The Journal of Consumer Research, 17(3):322332.

Muruganatham, G., \& Bhakat, R. S. (2013). A review of impulse buying Behaviour. International Journal of Marketing Studies, 5(3):149-160.

National Economic Development and labour Council (NEDLAC). (2005). A strategic assessment of the South African Sector. www.tips.prg.za/files/barnes_nedlac_clothing.pdf. Date retrieved: 16 February2014.

Norris, M., \& Lecavalier, L. (2009). Evaluating the use of exploratory factor analysis in Developmental Disability Psychological Research. Journal of Autism and Developmental Disorders, 40(1): 8-20.

Nunnally, J.C., \& Bernstein, I.H. (1994). Psychometric theory. New York: NY: McGraw-Hill.

O'Cass, A. (2004). Fashion clothing consumption: antecedents and consequences of fashion clothing involvement. European Journal of Marketing, 38(7):869-882.

O'Guinn, T., \& Faber, R. (1989). Compulsive buying: a phenomenological exploration. Journal Consumer Research, 16:147-157.

Overby, J. W., \& Lee, E. (2006). The Effects of Utilitarian and Hedonic Online Shopping Value on Consumer Preference and Intentions. Journal of Business Research, 59(10-11):1160-1166.

Park, E.J., Kim, E.Y., \& Forney, J.C. (2006). A structural model of fashion-oriented impulse buying behaviour". Journal of Fashion Marketing and Management, 10(40):433-446.

Park, M.J., \& Lennon, S. (2009). Brand name and promotion in online shopping contexts. Journal of Fashion Marketing and Management, 13(2):149-160.

Piron, F. (1991). Defining impulse purchasing. Advances in Consumer Research, 18:509-514.

Pett, M. A., Lackey, N. R., \& Sullivan, J. J. (2003). Making sense of factor analysis: the use of factor analysis for instrument development in health care research. Thousand Oaks: Sage.

Rook, D.W. (1987). The buying Impulse. Journal of Consumer Research, 14(2):189-199.

Rook, D.W., \& Gardner, M.P. (1993). In the mood: impulse buying's affective antecedents. Research in Consumer Behaviour, 22:305-313.

Rook, D. W., \& Fisher, R. J. (1995). Normative influences on Impulsive Buying Behaviour. The Journal of Consumer Research, 22:305-313.

Statistics South Africa. (2011). Income and expenditure household survey 2010/11. Pretoria, Government Printers. Available at:http://www.statssa.gov.za. Date accessed: 20 September, 2013.

Seo, J., Hathcote, J.M., \& Sweaney, A.L. (2001). Casual wear shopping behaviour of college men in Georgia, USA. Journal of Fashion Marketing and Management, 59(4): 361-378.

Solomon, M. (2004). Consumer behaviour. (6 $6^{\text {th }}$ ed.). Upper Saddle River, NJ: Prentice-Hall.

Stern, H. (1962). The significance of impulse buying today. Journal of Marketing, 26:59-62.

Tungate, M. (2008). Fashion brands: branding style from Armani to Zara. (2nd ed.). London: Kogan Page.

Verplanken, B., \& Herabadi, A. (2001). Individual differences in impulsive buying tendency: feeling and no thinking. European Journal of Personality, 15(1):71-83.

Virvilaitè, R., \& Saladienè, V. (2012). Models investigations of factors affecting consumer impulsive purchase behaviour in retail environment. Economics and Management, 17(2): 664-670.

Weinberg, P., \& Gottwald, W. (1982). Impulsive consumer buying as a result of emotions. Journal of Business Research, 10: $43-57$.

Wood, M. (1998). Socio-economic status, delay of gratification and impulse buying. Journal of Economic Psychology, 19(3): 295-320.

Youn, H.S. (2000). The dimensional structure of consumer buying impulsivity: measurement and validation. PhD, University of Minnesota, Minnesota.

Youn, S., \& Faber, R. J. (2000). Impulse buying: its relation to personality traits and cues. Advances in Consumer Research, 27:179-185. 